Article

\title{
The Role of Experience and Different Sources of Knowledge in Shaping Flood Risk Awareness
}

\author{
Elena Mondino ${ }^{1,2, *} \mathbb{C}$, Anna Scolobig ${ }^{3}$, Marco Borga ${ }^{4}$ and Giuliano Di Baldassarre ${ }^{1,2}$ (I) \\ 1 Department of Earth Sciences, Uppsala University, 75236 Uppsala, Sweden; \\ giuliano.dibaldassarre@geo.uu.se \\ 2 Centre of Natural Hazards and Disaster Science (CNDS), 75236 Uppsala, Sweden \\ 3 Environmental Governance and Territorial Development Institute, University of Geneva, \\ 1205 Geneva, Switzerland; anna.scolobig@unige.ch \\ 4 Department of Land, Environment, Agriculture and Forestry, University of Padua, 35122 Padua, Italy; \\ marco.borga@unipd.it \\ * Correspondence: elena.mondino@geo.uu.se
}

Received: 9 June 2020; Accepted: 22 July 2020; Published: 27 July 2020

\begin{abstract}
Understanding what makes people vulnerable to flooding is key in informing the risk management process. Non-structural measures, such as risk communication, can reduce vulnerability by improving flood risk awareness, but they require a deep understanding of which factors influence risk awareness, and how. We analysed and untangled the role of experience with, and knowledge of, floods by conducting a survey in a municipality in North-eastern Italy that was hit by a flash flood in 2018. The results show that previous experience with floods influences risk awareness not only directly, but also indirectly through the knowledge that was gained from that experience. In addition, specific (as opposed to generic) definitions of experience have been found to be better suited for exploring their effects on risk awareness. Based on the literature and on our results, we propose an experience-knowledge typology to help unravel the complex role that these two variables play in shaping flood risk awareness.
\end{abstract}

Keywords: flooding; natural hazards; risk awareness; sociohydrology

\section{Introduction}

Floods are among the most impacting natural hazards and are causing increasing damage globally [1]. In the past decade only, they caused damage for an estimated 360 billion US\$, nine times higher than in the 1980s [1]. Flood risk can be seen as a function of hazard, exposure, and vulnerability [2,3]. Over the past decades, flood risk management strategies shifted from a focus on structural protection measures to non-structural efforts-such as early warning systems, communication and awareness-raising campaigns, and relocation-aiming to reduce exposure or vulnerability [4-6]. While flood exposure keeps on increasing globally, mostly because of population growth, vulnerability to river flooding is declining worldwide [3]. Risk management efforts to increase the implementation of non-structural measures may have contributed to vulnerability reduction [7].

Understanding what makes people vulnerable to flooding is key in informing the risk management process. Often, flood vulnerability is associated with a lack of awareness of the natural surroundings. To this end, risk communication strategies can improve flood risk awareness [8], but, to tailor them properly, it is fundamental to understand what influences risk awareness and how it changes over time. The literature provides contradictory results about the key variables that influence flood risk awareness (a review is provided in [9]). This is the case for the variables "experience with the hazard" and "hazard/risk knowledge". Even if these two variables are included in almost every flood risk perception 
survey, few studies systematically analyse how they affect risk awareness, e.g., [9-11]. Moreover, the results are contradictory with respect to a) the different definitions and operationalizations of the variables "experience" and "knowledge" and b) the relationship between these variables and risk awareness.

\subsection{Heterogeneous Definitions of Experience}

Throughout the literature, definitions of experience are highly heterogeneous, going from generic to specific. Some scholars adopted damage severity as a proxy [12-16]. Others defined experience as having one's residence previously flooded, without investigating the severity of the consequences [16-21]. Evacuation during previous floods has also been employed as a proxy [10,17,22], even though it is not always a reflection of actual flood occurrence or flood damage. In many other cases, experience gained a much broader connotation. Ho et al. [23], Halpern-Felsher et al. [24], and Bustillos Ardaya et al. [22] use the number of times that one has generally been involved in a flood, without specifying the level of involvement. Others use a general previous experience with floods, without specifying whether it meant having one's home flooded or just witnessing a flood without experiencing damages [11,25-30]. Thistlethwaite et al. [31] investigated direct and indirect flood experience, with the latter including flood experience of relatives or friends. Becker et al. [32] adopted previous exposure as a proxy, asking whether the respondent's municipality had been hit by a flood in the recent years. Some authors did not even ask a question, but extrapolated the experience of the respondent from a combination of his/her age and place of residence [33]. In many, but not all, of these studies, the authors used a combination of different variables to describe flood experience. For instance, Scolobig et al. [27] used several variables, including previous flood experience and damage severity; Bradford et al. [17] used both previous flooding of the residence and evacuation. In addition, not all of the dimensions of experience can be captured and measured using only quantitative data and indicators. The experience of individuals is also influenced on some intangible aspects, such as agency, denial, or fatalism [34].

Our review also reveals that scholars use heterogeneous definitions of experience for multiple reasons, which may be context specific and/or instrumental, e.g., for data analysis. The characteristics of experience are not always the same in different situations and they need to be examined in their local environment/context and in relation to one another. For example, damage severity may be employed as a proxy in case of rather intense floods affecting a high percentage of the population. On the opposite, broader definitions—e.g., those including simply witnessing a flood as "experience"—-may be employed in cases of minimal damage to households or few people affected by the flood.

Finally, even though, in the majority of the cases, experience with floods is reported to positively contribute to risk awareness, in some it negatively correlates [24], in others it has unclear effects [14,17], yet in others it does not appear to be significant $[15,27]$.

\subsection{Risk Awareness and Risk Perception}

The different impacts that experience seems to have on flood risk awareness may be attributed to inconsistent definitions of the experience variable. However, they may also be the result of testing the variable on different risk awareness proxies. Within natural hazards literature, risk awareness is often used interchangeably with another term, risk perception. Both concepts are found in a number of different disciplines, ranging from psychology to geography, medicine, sociology, anthropology, and political sciences [30-35]. However, their meaning slightly differs. Risk awareness can be defined as knowledge of the presence of a risk, while risk perception can be defined as a broader "intuitive risk judgement" [36]. This means that our level of awareness and the way in which we perceive a certain hazard are doubtlessly correlated, but not interchangeable. While, in some cases, the difference is mainly in the wording and the authors who use awareness and those who use perception may still have the same concept in mind, in others this may not be true. Consequently, different proxies are then adopted to operationalise what is sometimes called risk awareness and sometimes risk perception [21]. These vary from the likelihood of a flood occurring in the future in their location $[10,19,21,25,36-38]$, 
the likelihood of a flood hitting their home/themselves [26], whether the respondents know they live in a risk zone $[16,18]$, or the probability of suffering financial damages $[10,21]$. Some scholars ask the respondents to rate their personal flood risk as compared to that of others [10], or to what extent they thought floods were a threat to themselves or others [21,25].

\subsection{Information and Knowledge}

Dretske [39] acknowledged that "there is a difference between hearing Clyde play the piano and seeing him play the piano". In a similar way, we acknowledge that there is a difference between imagining and experiencing a flood. The creation of a mental imagery about a flood that we have not experienced directly can also affect our risk awareness, especially because visual cognition/imagery facilitates learning and memory [40].

Mental imagery can be further stimulated by acquiring historical, physical, geographical, and many other types of information [41], which, in turn, can contribute to individual flood knowledge. Thus, knowledge is certainly not only a product of direct flood experience. Sources of information can be e.g., books, hazard and risk assessments, maps, urban plans, and historical archives. Moreover, information can be provided through different channels, including official sources (e.g., public authorities) and informal networks (e.g., friends). Personal research is also an increasingly relevant source of information, especially through internet/on-line searches. Formal education-from primary school to University-is also a critical source of knowledge about floods and natural hazards more in general.

In this context, it is critical to distinguish between an individual's self-assessed knowledge and his/her scientific knowledge of a phenomenon (as assessed, for instance, by [10]). Not only can the two potentially not always match [37,38], but they can also have different effects on the dependent variables under study. In the psychometric paradigm, knowledge is defined as people's perception of how well they know a risk, and of how well a risk is known to science [40-43]. Fischoff et al. [44,45], found that, if risks were adjusted to an acceptable level, then people were more likely to accept higher risk levels for risks they felt they knew more about. They also found correlations between knowledge and other variables, such as controllability (negative correlation), newness (negative correlation), and voluntary exposure (positive correlation). In summary, the majority of studies revised for this paper operationalise individual hazard knowledge as self-assessed knowledge (a review in [46,47]).

In outlining the role of knowledge in disaster risk reduction, Weichselgartner \& Pigeon [48] clearly emphasise the dynamic character of knowledge, which is built through social interactions that shape the data, information, and facts that each individual is processing. In fact, the creation of knowledge does not happen merely by providing new data/information, but rather when such information is processed. In this regard, it is also worth mentioning that individuals with lower self-assessed knowledge tend to be more receptive when it comes to processing new information [42]. From a risk communication point of view, this implies that individuals with a higher self-assessed knowledge, those who feel they "know a lot" about the hazards, may also be those less interested in receiving or searching for new information. However, individuals with a higher self-assessed knowledge may also be those who are more familiar with the hazard. In this sense, familiarity refers to the extent to which people have become accustomed to a risk [46]. Here, the concept of familiarity brings together knowledge and experience: a person who experienced a number of floods can get accustomed to the event and his/her self-assessed knowledge about it may increase.

Our work aims to contribute to the scientific debate about the relationship between sources of knowledge, experience, and awareness by unravelling the role of experience and self-assessed knowledge derived from different sources in shaping flood risk awareness. This can inform future research on flood risk perceptions, especially when it comes to the variables' operationalisation, in order to avoid unclear or even contradictory results due merely to the selection of survey questions. To this end, we conducted a survey in a municipality in North-eastern Italy, recently hit by a flash flood. We adopted a set of independent variables - all potential proxies for experience and knowledge-that we regressed on a set of variables for flood risk awareness. In doing this, we considered various aspects 
that can be representative of one's experience with and self-assessed knowledge of floods, both directly and indirectly.

The following section will present the study area, the sampling methodology adopted, and the operationalization of the variables. Section 3 will present the results. In Section 4, the results are discussed and a new typology for risk awareness that is based on experience and knowledge is presented.

\section{Materials and Methods}

The study area is the municipality of Negrar, located in the Veneto Prealps, north of Verona. The municipality ranges between 70 and $860 \mathrm{~m}$ a.s.l. Three streams (locally known as progni) flow through the municipality, progno di Negrar, Fosson, and progno di Novare, all flowing into the Adige river downstream. Negrar is divided into smaller urban conglomerates that are mainly located in the floodplain in the lower part of the municipality. The population steadily increased in the past years and it amounts to approximately 17,093 residents as of 2018.

On September 1st, 2018 Arbizzano-Santa Maria, one of the small urban conglomerates of Negrar, was hit by a flash flood [48,49]. After heavy rainfall that accumulated more than $180 \mathrm{~mm}$ in less than three hours, progno di Novare $\left(2 \mathrm{~km}^{2}\right.$ at the section where it enters the urban settlement) overflowed and inundated the nearby buildings, with the flood peak reaching $20 \mathrm{~m} 3 / \mathrm{s}$ [50]. Because of its intensity, this flash flood is characterized by more than a 100-year return period. The event caused serious economic damage ( $\sim 10$ million $€$ ), and even though there were no casualties, around 3000 people were affected.

The data collection was mainly focused in Arbizzano-Santa Maria (population ca. 4000), the conglomerate most heavily impacted by the September 2018 flash flood (see Figure 1). In 2014, the area experienced a similar event, but with a much lower magnitude. In the past century, only one other significant flood event was recorded, in 1935, which caused significant damages and casualties. To this day, the small flooding of basements often occurs in case of heavy rain, especially concerning households located near the streams, in areas that were heavily urbanized in the second half of the 1980s. The Veneto region, where the study area is located, experienced major flooding in the past decades, and the area shows an increase in flood events [51,52]. Nevertheless, the municipality does not have flood risk maps in place at the communal level, and the flood risk assessment at the Adige river basin level (known as Piano di Assetto Idrogeologico dell'Adige), characterized by a low resolution, does not report any flood risk for the municipality.

Flood response data collection was based on a post flood survey, including radar rainfall reanalysis, the estimation of flood peaks based on high water marks, and consistency analysis based on flood modelling, following the methodology that was described by Amponsah et al. [53] and Borga et al. [54]. Social data collection was based on retrieving data from existing sources, such as census data and provincial archives, and a questionnaire survey carried out through face-to-face interviewing of the residents of Arbizzano-Santa Maria. We opted for a stratified sample of residents based on quotas [55], since a random sample would not be fit for purpose, as it might result in the exclusion or underrepresentation of those residents of particular interest to us (that is, those living in the most risky areas and the households most affected by the 2018 flood). We constructed a sample stratified according to age and gender (Italian National Census data). To respect the statistical distribution of these variables in the local population, we provided each interviewer with some grids containing the target distribution of interviewees. The demographic data were provided by the Civil Registry of Negrar. Moreover, the administration provided a list of residents that were affected by the flash flood who agreed to be interviewed. The interviewers first contacted the people on the list via phone calls to set appointments for the interviews. This preliminary step was fundamental to establish trust in the local community. In turn, the residents already interviewed helped the interviewers establish trust with neighbours in order to facilitate the interviewing process in households affected by the 2018 flood and avoid unnecessary nuisance. In parallel, the interviewers received a map of the study area 
and contacted each household in each and every street, to maximise randomisation and, at the same time, fill in the quotas that are required for age and gender. The unit of analysis was the individual, and interviewees were instructed to contact only one person per household and to interview her/him face to face. The necessity to interview only one person per household is due to the presence of questions relating to the adoption of protection measures within the household that are not discussed in the present paper, but are extensively presented in Weyrich et al. [56]. Thus, interviewing more than one person per household would have led to the creation of duplicates for the questions about the adoption of protection measures.

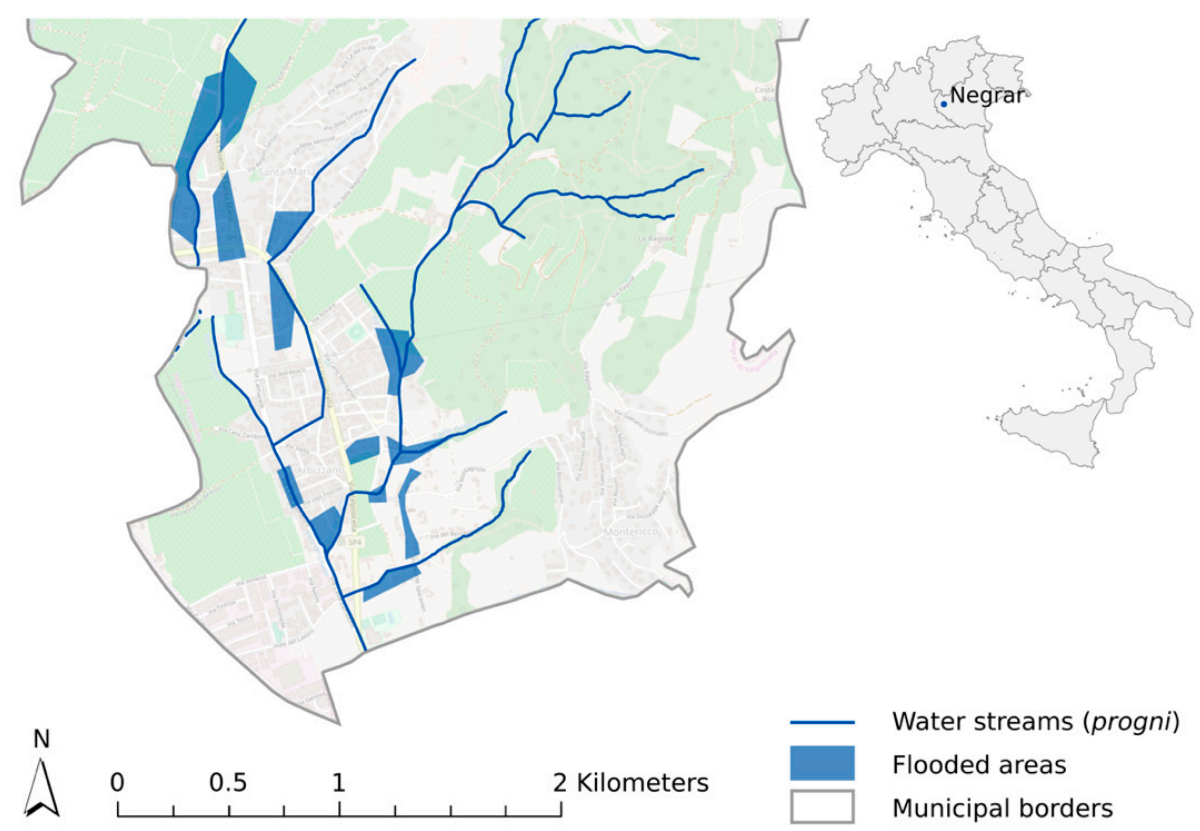

Figure 1. Study site location and flooded areas.

Data were collected throughout a two-week period from 18 February to 1 March 2019, approximately six months after the event. The survey was approved by the local authorities. Participants received no incentive to complete the survey, which took them, on average, about 30 minutes. A total of 146 residents completed the survey. Respondents ranged in age from 20 to 89 years $(\mathrm{M}=53.38, \mathrm{SD}=17.99)$, and $n=77(52.7 \%)$ were female. When compared to the average population in Negrar, the sample was slightly older than the average $(\mathrm{M}=44.7$ years), similar for the gender ratio of female (50.4\%) and male (49.6\%). Slightly more than half of the respondents (56\%) reported some sort of damage caused by the flooding event of September 2018.

We used eight variables to explore respondents' experience with floods, as briefly mentioned in Section 2. They are divided into two main groups below. One group includes variables that describe experience with flooding events, while the other group includes variables that describe the self-assessed knowledge the respondents may have gathered on floods throughout their life and through personal experiences. The length of residence was included to test experience, as it was operationalized by Steinführer and Kuhlicke [33]. Table 1 shows each variable together with the related question and available answers. Table 2 lists the variables employed to test awareness. The questionnaire included, in total, 68 items and it is available in the Supplementary materials. 
Table 1. Independent variables.

\begin{tabular}{|c|c|c|}
\hline Variable name & Question & Answer Options * \\
\hline General feeling of safety & $\begin{array}{c}\text { In general, how safe do you feel living in this } \\
\text { area? }\end{array}$ & $\begin{array}{c}\text { On a scale from } 1 \text {, "Not at all safe" } \\
\text { to 5, "Very safe", } \\
\text { or } 0 \text {, "I don't know" }\end{array}$ \\
\hline \multicolumn{3}{|l|}{ Experience } \\
\hline $\begin{array}{c}\text { Presence during the } 2018 \\
\text { event }\end{array}$ & Were you present during the 2018 event? & 1. Yes; 2. No \\
\hline Previous flood experience & $\begin{array}{c}\text { Were you ever involved in a similar event in } \\
\text { the past, here or elsewhere? }\end{array}$ & 1. Yes; 2. No \\
\hline Damage severity & $\begin{array}{c}\text { Can you evaluate the severity of the damage } \\
\text { suffered by yourself or your house? }\end{array}$ & $\begin{array}{l}\text { On a scale from } 1 \text {, “No damage" to } \\
5 \text {, "Serious damage", or 0, "I don't } \\
\text { know" }\end{array}$ \\
\hline $\begin{array}{l}\text { Length of residence } \\
\text { Knowledge }\end{array}$ & For how long have you been living here? & 1. Since birth; 2. Since ___ (year) \\
\hline $\begin{array}{l}\text { Knowledge from direct } \\
\text { experience }\end{array}$ & $\begin{array}{l}\text { How much did direct experience with the } \\
\text { event contribute to your knowledge of floods? }\end{array}$ & $\begin{array}{c}\text { On a scale from 1, "No } \\
\text { contribution" to 5, "Great } \\
\text { contribution", or 0, "I don't know" }\end{array}$ \\
\hline $\begin{array}{l}\text { Information passed on by } \\
\text { others }\end{array}$ & $\begin{array}{l}\text { How much did information passed on by } \\
\text { others (parents, relatives, friends, etc.) } \\
\text { contribute to your knowledge of floods? }\end{array}$ & $\begin{array}{l}\text { On a scale from } 1, \text {,No } \\
\text { contribution" to } 5 \text {, "Great } \\
\text { contribution", or } 0 \text {, “I don't know" }\end{array}$ \\
\hline $\begin{array}{l}\text { Information from official } \\
\text { sources }\end{array}$ & $\begin{array}{c}\text { How much did official information contribute } \\
\text { to your knowledge of floods? }\end{array}$ & $\begin{array}{c}\text { On a scale from 1, "No } \\
\text { contribution" to 5, "Great } \\
\text { contribution", or 0, "I don't know" }\end{array}$ \\
\hline $\begin{array}{l}\text { Personal research of } \\
\text { information }\end{array}$ & $\begin{array}{l}\text { How much did your personal research for } \\
\text { information contribute to your knowledge of } \\
\text { floods? }\end{array}$ & $\begin{array}{c}\text { On a scale from 1, "No } \\
\text { contribution" to 5, "Great } \\
\text { contribution", or 0, "I don't know" }\end{array}$ \\
\hline $\begin{array}{c}\text { Threat appraisal before the } \\
\text { event }\end{array}$ & $\begin{array}{l}\text { Before the } 2018 \text { event, did you think } \\
\text { something like this could occur here? }\end{array}$ & 1. Yes; 2. No; 0. I don't know \\
\hline
\end{tabular}

Table 2. Dependent variables.

\begin{tabular}{|c|c|c|}
\hline Variable name & Question & Available Answers* \\
\hline Perceived threat to self & $\begin{array}{c}\text { Considering floods, to what extent do } \\
\text { you think they represent a threat to } \\
\text { yourself personally? }\end{array}$ & $\begin{array}{l}\text { On a scale from } 1 \text {, “Not at all a } \\
\text { threat" to } 5 \text {, "Serious threat", } \\
\text { or } 0, \text { "I don't know" }\end{array}$ \\
\hline Perceived threat to home & $\begin{array}{c}\text { Considering floods, to what extent do } \\
\text { you think they represent a threat to } \\
\text { your home? }\end{array}$ & $\begin{array}{l}\text { On a scale from } 1, \text { "Not at all a } \\
\text { threat" to } 5 \text {, "Serious threat", } \\
\text { or } 0, \text {,I don't know" }\end{array}$ \\
\hline $\begin{array}{l}\text { Perceived threat to town as a } \\
\text { whole }\end{array}$ & $\begin{array}{c}\text { Considering floods, to what extent do } \\
\text { you think they represent a threat to } \\
\text { the town as a whole? }\end{array}$ & $\begin{array}{l}\text { On a scale from } 1, \text { "Not at all a } \\
\text { threat" to } 5 \text {, "Serious threat", } \\
\text { or } 0, \text { "I don't know" }\end{array}$ \\
\hline $\begin{array}{l}\text { Perceived threat from other types } \\
\text { of hazard }\end{array}$ & $\begin{array}{c}\text { Considering (hazard), to what extent } \\
\text { do you think it represents a threat to } \\
\text { the town as a whole? }\end{array}$ & $\begin{array}{l}\text { On a scale from } 1 \text {, “Not at all a } \\
\text { threat" to 5, "Serious threat", } \\
\text { or 0, "I don't know" }\end{array}$ \\
\hline Expected future damage & $\begin{array}{c}\text { How much damage do you think a } \\
\text { potential future flood could cause to } \\
\text { your home? }\end{array}$ & $\begin{array}{c}\text { On a scale from } 1 \text {, "No damage" to } \\
5, \text { "Serious damage", } \\
\text { or 0, "I don't know" }\end{array}$ \\
\hline
\end{tabular}

* "I don't know" answers were categorized as NA and excluded from the analysis; ** Earthquake, robbery, drought, terror attack, fire.

The statistical analysis was conducted using the software for statistical computing $\mathrm{R}$ (version 3.5.2.). We used the package "ordinal" [57], developed for analysing ordinal data, to run multiple single ordinal logistic regressions (ordered logit), a type of regression model adopted when the dependent variable has an ordinal nature. In this case, all of the dependent variables are ordinal, i.e., the respondents had to reply on an ordered discrete scale from 1 to 5 . We adopted a $95 \%$ confidence interval. The $p$-values 
have been adjusted with the Hochberg correction. The next section presents the results of the statistical analysis.

\section{Results}

The majority of respondents feel relatively safe living in the area, with the majority of respondents reporting $4(41 \%)$ or $5(31 \%)$ on the ( $1 \mathrm{~min} .5 \mathrm{max})$ Likert-type scale. When it comes to the perceived threat caused by floods (see Figure 2), respondents show a much greater concern for the town as a whole compared to themselves. These results show an optimistic bias in the interviewees' responses about flood risk awareness. Indeed, the respondents tend to see themselves in a safer position when compared to the town as a whole. Robbery seems to be the greater concern when it comes to personal safety, followed by earthquakes. Drought, fires, and terror attacks are not concerning to the residents.

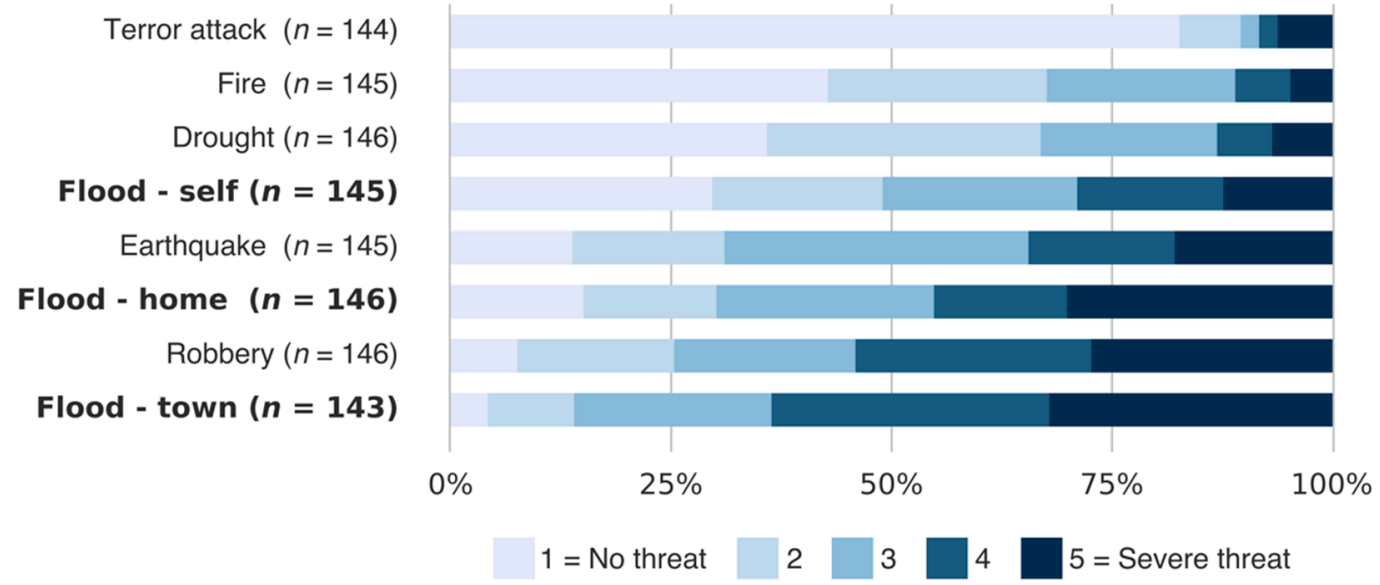

Figure 2. Survey results on perceived threat.

The majority of respondents (82\%) were present during the 2018 flood event, but only $22 \%$ reported having experienced a similar event in the past. This may be attributed to the fact that $75 \%$ of respondents live in the area for more than 20 years, and only few other milder floods have occurred in the past. Indeed, the majority (74\%) never thought that a similar event could occur in the study area. In general, the respondents consider their income sufficient or more than sufficient to satisfy their household needs, with the majority reporting $3(45 \%), 4(19 \%)$, or $5(20 \%)$, on the (1 min. 5 max) scale. Slightly more than half of the respondents reported some sort of damage caused by the 2018 event (56\%).

\subsection{Flood Experience}

The results from the ordered logits show that different experience proxies influence different facets of the perceived threat (see Table 3). Respondents who were present during the 2018 event are three times more likely to report a higher perceived threat to themselves personally, while this variable does not seem to affect the perceived threat to their home and to the town as a whole, or expected future damage. On the other hand, respondents who experienced greater damages during the 2018 event are two and a half times more likely to report a higher perceived threat to their home and one and a half times more likely to report a higher expected future damage. Having experienced an event prior to the 2018, one does not seem to directly influence the respondents' perceived threat to either their home, self, town as a whole, or expected future damage. The length of residence in the area does not influence any of the awareness proxies, but this is likely due to the majority of respondents $(\sim 70 \%)$ moving in the area in the 1980s, and no major event occurring in the past 30-40 years. Even though some respondents reported the occurrence of a flood in 2014, this was an event with a much lower magnitude as compared to the 2018 flood, and it affected a much lower fraction of the local population. 
Table 3. Odds Ratios resulting from the single regressions.

\begin{tabular}{|c|c|c|c|c|}
\hline \multirow[t]{2}{*}{ Independent variables } & \multicolumn{3}{|c|}{$\begin{array}{l}\text { Perceived } \\
\text { Threat }\end{array}$} & \multirow[t]{2}{*}{$\begin{array}{c}\text { Expected } \\
\text { Future Damage }\end{array}$} \\
\hline & Self & Home & Town & \\
\hline $\begin{array}{l}\text { General feeling } \\
\text { of safety }(-)\end{array}$ & $\begin{array}{l}1.79 * * \\
(1.29-2.50)\end{array}$ & $\begin{array}{l}1.94^{* *} \\
(1.38-2.76)\end{array}$ & $\begin{array}{l}1.56 \\
(1.11-2.20)\end{array}$ & $\begin{array}{l}1.73^{* *} \\
(1.24-2.42)\end{array}$ \\
\hline \multicolumn{5}{|l|}{ Experience } \\
\hline $\begin{array}{l}\text { Presence during } 2018 \\
\text { event }\end{array}$ & $\begin{array}{l}3.03 * \\
(1.47-6.72)\end{array}$ & $\begin{array}{l}0.60 \\
(0.28-1.25)\end{array}$ & $\begin{array}{l}0.81 \\
(0.38-1.74)\end{array}$ & $\begin{array}{l}1.58 \\
(0.73-3.44)\end{array}$ \\
\hline Damage severity in 2018 & $\begin{array}{l}1.2 \\
(0.98-1.48)\end{array}$ & $\begin{array}{l}2.45^{* * *} \\
(1.87-3.27)\end{array}$ & $\begin{array}{l}1.22 \\
(0.98-1.52)\end{array}$ & $\begin{array}{l}2.70 * * * \\
(2.07-3.60)\end{array}$ \\
\hline Previous experience & $\begin{array}{l}0.99 \\
(0.50-1.97)\end{array}$ & $\begin{array}{l}0.68 \\
(0.34-1.35)\end{array}$ & $\begin{array}{l}0.64 \\
(0.31-1.31)\end{array}$ & $\begin{array}{l}1.62 \\
(0.78-3.37)\end{array}$ \\
\hline Length of residence & $\begin{array}{l}1.37 \\
(1.02-1.83)\end{array}$ & $\begin{array}{l}1.46 \\
(1.08-2.02)\end{array}$ & $\begin{array}{l}1.38 \\
(1.01-1.94)\end{array}$ & $\begin{array}{l}1.00 \\
(0.99-1.02)\end{array}$ \\
\hline \multicolumn{5}{|l|}{ Knowledge } \\
\hline From direct experience & $\begin{array}{l}1.40 * \\
(1.11-1.76)\end{array}$ & $\begin{array}{l}1.41^{* *} \\
(1.14-1.77)\end{array}$ & $\begin{array}{l}1.45^{* *} \\
(1.17-1.80)\end{array}$ & $\begin{array}{l}1.39 * \\
(1.13-1.72)\end{array}$ \\
\hline Passed on by others & $\begin{array}{l}1.36^{*} \\
(1.12-1.66)\end{array}$ & $\begin{array}{l}1.18 \\
(0.98-1.44)\end{array}$ & $\begin{array}{l}1.21 \\
(0.99-1.49)\end{array}$ & $\begin{array}{l}1.04 \\
(0.86-1.26)\end{array}$ \\
\hline From official information & $\begin{array}{l}0.99 \\
(0.77-1.27)\end{array}$ & $\begin{array}{l}0.98 \\
(0.75-1.25)\end{array}$ & $\begin{array}{l}1.05 \\
(0.81-1.35)\end{array}$ & $\begin{array}{l}0.90 \\
(0.70-1.16)\end{array}$ \\
\hline From personal research & $\begin{array}{l}1.10 \\
(0.90-1.33)\end{array}$ & $\begin{array}{l}1.11 \\
(0.91-1.35)\end{array}$ & $\begin{array}{l}1.10 \\
(0.90-1.39)\end{array}$ & $\begin{array}{l}1.07 \\
(0.88-1.30)\end{array}$ \\
\hline $\begin{array}{l}\text { Threat appraisal before the } \\
\text { event }\end{array}$ & $\begin{array}{l}2.99 * * \\
(1.51-6.02)\end{array}$ & $\begin{array}{l}0.65 \\
(0.33-1.30)\end{array}$ & $\begin{array}{l}0.78 \\
(0.39-1.55)\end{array}$ & $\begin{array}{l}1.07 \\
(0.54-2.11)\end{array}$ \\
\hline \multicolumn{5}{|l|}{ Socio-economic } \\
\hline Gender & $\begin{array}{l}1.85 \\
(1.03-3.35)\end{array}$ & $\begin{array}{l}1.69 \\
(0.95-3.04)\end{array}$ & $\begin{array}{l}2.61 * \\
(1.43-4.85)\end{array}$ & $\begin{array}{l}2.44 * \\
(1.35-4.46)\end{array}$ \\
\hline Education (-) & $\begin{array}{l}1.30 \\
(0.99-1.71)\end{array}$ & $\begin{array}{l}1.06 \\
(0.82-1.38)\end{array}$ & $\begin{array}{l}1.23 \\
(0.92-1.62)\end{array}$ & $\begin{array}{l}1.04 \\
(0.80-1.34)\end{array}$ \\
\hline Income $(-)$ & $\begin{array}{l}1.44 \\
(1.10-1.89)\end{array}$ & $\begin{array}{l}1.13 \\
(0.87-1.47)\end{array}$ & $\begin{array}{l}1.65^{* *} \\
(1.23-2.22)\end{array}$ & $\begin{array}{l}1.07 \\
(0.83-1.40)\end{array}$ \\
\hline
\end{tabular}

(-) indicates a negative effect; 95\% confidence interval in brackets; $p<0.001^{* * *}, p<0.01^{* *}, p<0.05$ * (Hochberg adjusted).

\subsection{Sources of Flood Risk Knowledge}

Rather than assessing the individual flood risk knowledge, we analysed the influence of different sources of information on individual knowledge. Sources included direct experience, other people, official information, and personal research. The results show that it is primarily direct experience with floods, followed by personal research of information, and knowledge passed on by others that contribute to personal flood risk knowledge. Remarkably, official sources play a minor role (see Figure 3). 


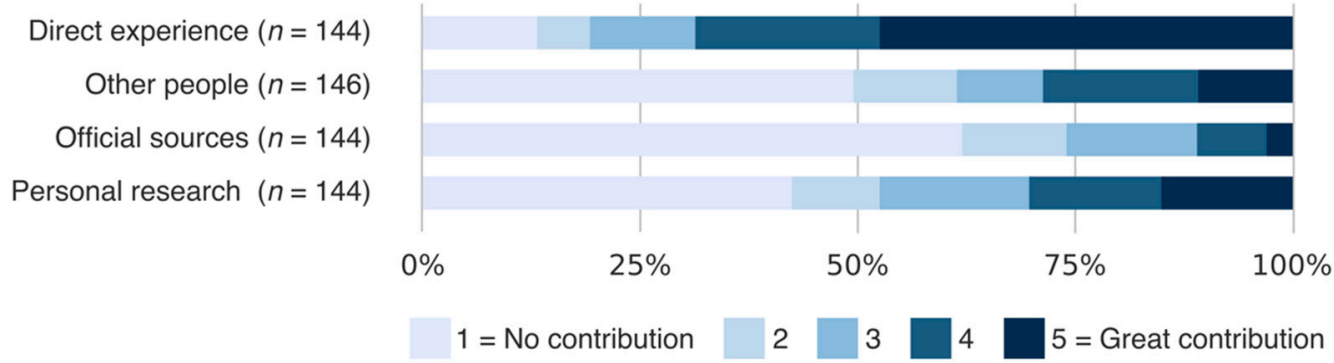

Figure 3. Survey results on self-assessed knowledge.

The respondents who report that direct experience with the hazard contributed to their knowledge are also more likely to report a higher perceived threat to their home, self, town as a whole, and higher expected future damage (see Table 3). When it comes to other sources of knowledge, secondary knowledge passed on from relatives or friends is the only variable that has an effect. The respondents with a greater knowledge passed on from others are more likely to report a higher perceived threat to themselves personally. Respondents who thought that a similar event could occur in the study area, i.e., those with a higher threat appraisal before the event, were also more likely to report a higher perceived threat to themselves. Even though the knowledge derived from personal research of information does not affect any of the awareness proxies, it is worth mentioning that the percentage of respondents who gave it a score of 4 or 5 is much higher as compared to the one found by De Marchi et al. [34] (31\% vs. $15 \%)$. We attribute this to the increased access to information, especially via the Internet, as compared to 2005, when De Marchi et al. conducted their survey.

Following the above testing, we investigated which of the variables related to experience (damage severity, presence during the event, previous experience, length of residence) contributed to the knowledge deriving from direct experience (see Table 4). We found that experiencing damages has the greater impact, and that having experienced a similar event in the past also contributes to greater knowledge from direct experience. However, simply witnessing the phenomenon was not found to significantly influence respondents' knowledge of the hazard itself. Similarly, having lived in the area for a longer time is also not an assurance of having a higher knowledge of the phenomenon.

Table 4. Odds Ratios resulting from the multiple single regressions on the knowledge deriving from direct experience.

\begin{tabular}{cc}
\hline Independent Variables & Knowledge From Direct Experience \\
\hline Damage severity in 2018 & $1.59(1.24-2.08)^{* * *}$ \\
Presence during 2018 event & $1.35(0.62-2.95)^{* *}$ \\
Previous experience & $2.60(1.24-5.77)^{*}$ \\
Length of residence & $1.00(0.98-1.02)^{* *}$ \\
\hline $95 \%$ confidence interval in brackets; $p<0.001^{* * *}, p<0.01^{* *}, p<0.05^{*}$.
\end{tabular}

\subsection{Socio-Economic Variables}

Concerning socio-economic variables, women seem to be more worried than men when it comes to the threat to the town as a whole, and they are also more likely to expect greater damage should a flood occur again. This is in line with previous literature (e.g., $[13,48])$. People with a higher income are less likely to think that the town, as a whole, is threatened by floods. This may be due to the fact that, in the study area, people with higher incomes tend to live in hillside houses that are further away from the floodplain. Education does not show any significant influence on the awareness proxies selected, but this could be due to the narrow range of the distribution, with the majority of the surveyed population $(74 \%)$ having a high school diploma or higher. 


\section{Discussion}

In the previous section, we presented the results from the ordered logits and showed that the influence of experience on awareness is multifaceted. Being present during the event, which means witnessing the event with one's own eyes, particularly influences the perceived threat to oneself. We hypothesized that this is because witnessing the event allows for us to imagine what could happen if we were caught by the flood. On the other hand, suffering damages to the household greatly impacts the awareness proxies that are related to the home, such as the perceived threat to the home and the expected damage should a flood occur in the future. These results show the importance of selecting adequate experience variables, depending on what aspect of risk awareness we want to explore. Indeed, the generic variable "previous experience with floods" does not significantly influence any of the awareness proxies used here. Interestingly though, it positively influences the knowledge derived from direct experience, which, in turn, positively influences all aspects of risk awareness explored. These results are surprisingly telling, as they show that previous experience (in whatever form) influences risk awareness not only directly, but indirectly through the knowledge that was gained from that experience. It is not only the previous experience itself that increases our awareness, but what we learn from it and how we process it. From a risk communication point of view, this finding points to the importance of informing residents not only before an event occurs, but also after, exploiting the sudden attention that is given to the phenomenon. This window of opportunity was also emphasized by de Vries [58,59], who stresses that the post-disaster period before the return to normalcy can be used by managers to promote change, e.g., in terms of adaptive behaviour. Knowledge deriving from direct experience is also higher in those that suffered damage during the 2018 flood, as expected. Directly experiencing a flood-in terms of suffering damage to oneself or the home-has already been found to significantly influence respondents' risk awareness in previous studies (e.g., $[16,18,19])$.

In light of the results previously discussed, and the lack of robust literature on the role of self-assessed knowledge derived from experience, we suggest future research on the role of experience should particularly focus on the knowledge that may derive from experiencing a flood, as this case shows that it heavily influences respondent's risk awareness. In particular, it will be useful to distinguish which type of experience contributes to a greater knowledge and, in turn, to a greater awareness. To this end, we propose a typology that is based on two factors: direct experience with the hazard and self-assessed knowledge (see Figure 4). Direct experience is characterized by both intensity (how strong) and frequency (how often) of the experience itself. The typology consists of four types:

- Inertia: this type includes individuals who lack or have a low degree of both experience and knowledge, who are therefore less familiar or not familiar at all with the hazard, in a state of inertia, passivity;

- Tacit/empirical knowledge: this type includes individuals who only experienced the event but who did not gain any information (or gained very limited information) from other sources of knowledge;

- Theoretical knowledge: this type includes individuals who only gained information from other sources of knowledge but who never experienced the hazard; and,

- Wisdom: this type includes individuals who experienced the hazard and who gained information from various sources of knowledge, who therefore reached wisdom by integrating experience and knowledge.

The concept of theoretical knowledge was first brought up by Aristotle in his work titled Nicomachean Ethics, in 350 B.C. In Book VI [60], he argued that theoretical knowledge is the one of the spectator, i.e., what comes from "standing back" and "looking on". In this context, the spectator can be the one who gains knowledge from secondary sources, without having experienced any flood. The concept of tacit knowledge was theorized by Polanyi [61], who described it as a knowledge that comes from direct experience, hidden and implicit. In philosophy, it is better known as empirical 
knowledge, which is knowledge derived from experience, as opposed to knowledge derived from deductive reasoning or theory.

This typology contributes to unraveling the complex role of experience and knowledge in shaping risk awareness and, in turn, our attitudes toward the hazard. In addition, it can inform future research on the types of variables to explore and their operationalization. In particular, the adoption of generic variables is discouraged, as they do not show statistical significance if compared to other, more precise variables (such as amount of damage experienced), as shown by the results of this survey.

Regarding the contribution of other sources of knowledge, information passed on from relatives or friends is the only one to influence the perceived threat to self. We attribute this to the fact that suggestive stories told by family members who may have previously been involved in similar events trigger a feeling of danger, as respondents tend to trust their experiences and create mental imagery about the event. This also supports the claim by Weichselgartner et al. [48], whereby, while information is static, knowledge is dynamic and social interactions shape the data, information, and facts that each individual is processing. However, even though the information that is passed on by others plays a role in influencing flood risk awareness, the percentage of respondents reporting that they gained knowledge from others is still quite low ( $50 \%$ reported 1 and $12 \%$ reported 2 on the ( 1 min 5 max) scale). We attribute such a low level of local knowledge to the recent urbanization of the area, which started in the 1980s. It is possible that the community knowledge was lost as a consequence of population growth in the area, considering also that many of the residents live in the municipality, but work in the urban center of Verona. This supports results of other studies, showing that rapid urbanization processes may decrease community resilience, primarily due to a loss of local knowledge [34].

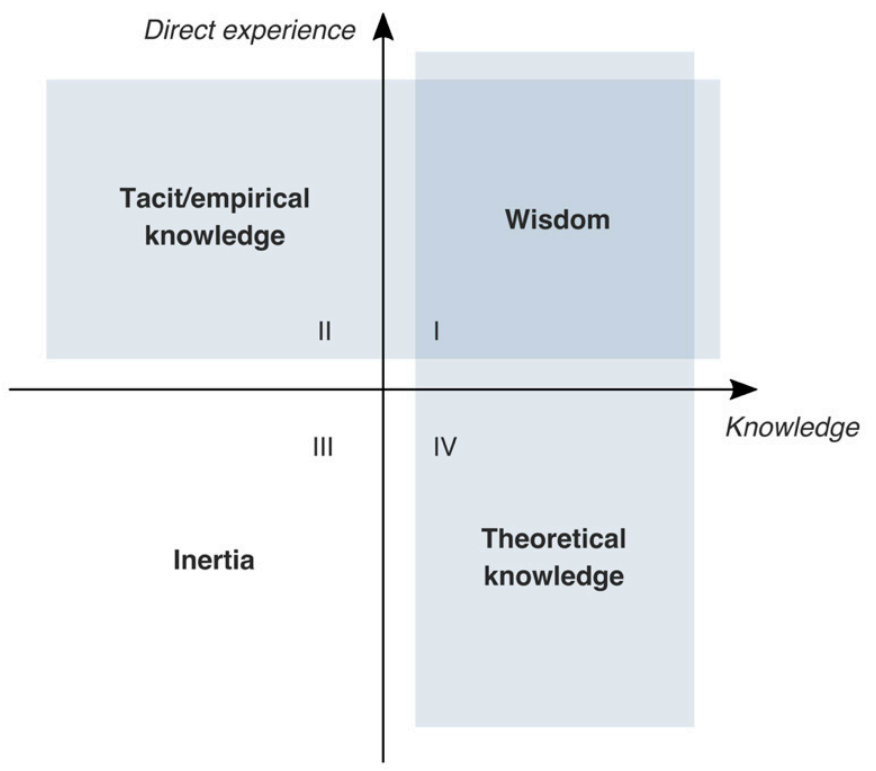

Figure 4. Experience-knowledge typology.

While this study contributes to untangling the complex role of experience and knowledge in shaping flood risk awareness, it comes with some limitations. The sample size is rather small, and this is a consequence of two factors: the surveys were administered face-to-face, which is rather time consuming, and we only surveyed one person per household to avoid duplicates. We did not investigate the actual scientific knowledge of the residents about floods. Having this information would have allowed for a comparison between actual and self-assessed knowledge, which would have brought an added value to the analysis.

Based on our results and discussion, we recommend that future studies that assay the role of experience should take into consideration not only the experience in itself (in terms of intensity and frequency), but also, and especially, the knowledge produced as a result of the experience and the 
knowledge acquired through secondary sources. The inclusion of variables to investigate the actual knowledge of residents on flood risk in their area can provide an additional dimension to the analysis, allowing for a comparison among the potentially different effects that self-assessed knowledge and actual knowledge have on risk awareness. Another critical aspect to consider is the specificity of the variables to investigate flood experience: the more specific the variable, the more trustworthy the result, as there is less room for interpretation by the respondent. It is eventually to be noted that, given the intrinsic cultural aspects that are involved in variables, like awareness and knowledge, differences should be expected should this typology be applied in different countries and regions.

In conclusion, the results of this paper and the presented typology contribute to the scientific debate on the relationship between sources of knowledge, experience, and awareness by unravelling the role of experience and self-assessed knowledge derived from different sources in shaping flood risk awareness. Besides providing a sound base for future operationalization of the variables, this work can inform risk communication strategies on the importance of valuing residents' experience of floods-and the deriving knowledge-and exploit the window of opportunity after the event to communicate risk and inform the local population.

Supplementary Materials: The following are available online at http://www.mdpi.com/2073-4441/12/8/2130/s1.

Author Contributions: Conceptualization, E.M., A.S., M.B. and G.D.B.; questionnaire design, A.S., E.M., and M.B.; data collection, E.M.; statistical analysis, E.M.; contact with local administrations, M.B.; writing-original draft preparation, E.M.; writing-review and editing, E.M., A.S., M.B., and G.D.B.; funding acquisition, G.D.B. All authors have read and agreed to the published version of the manuscript.

Funding: GDB was supported by the European Research Council (ERC) within the project "HydroSocialExtremes: Uncovering the Mutual Shaping of Hydrological Extremes and Society" [ERC Consolidator Grant no. 771678]. Part of the survey questions have been developed in the EC Sixth Framework Programme funded project FLOODsite, 2004-2008 (http://www.floodsite.net) Contract GOCE-CT-2004-505420. At the time of the FLOODsite research project Anna Scolobig was associated with ISIG (Institute of International Sociology of Gorizia, Italy), one of the FLOODsite partners.

Acknowledgments: We wish to deeply thank the-at the time of FLOODsite research-leader of the Mass Emergency Programme at ISIG, Bruna De Marchi for having considerably contributed to the survey design. The same is true for Professor Giovanni Delli Zotti and Maura Del Zotto, two of the other ISIG team members. We also thank all the other colleagues who provided us with professional advice and collaboration, and the interviewers who helped conduct the survey, Giacomo Bernello, Giulia Bisoffi, Viviana Bort, Elena Poli, and Federico Professione. We also want to acknowledge the municipality of Negrar for their collaboration and for providing demographic data, especially Lorenzo Calabria who considerably helped in bridging the interviewers with the residents. Finally, we acknowledge Julian Baur for providing advice on the statistical analysis, Philippe Weyrich for providing suggestions and comments on the manuscript, and Bonita Mathew for proofreading the submitted manuscript.

Conflicts of Interest: The authors declare no conflict of interest. The funders had no role in the design of the study; in the collection, analyses, or interpretation of data; in the writing of the manuscript, or in the decision to publish the results.

\section{References}

1. Guha-Sapir, D.; Below, R.; Hoyois, P. EM-DAT: The CRED/OFDA International Disaster Database; Catholic University of Leuven: Leuven, Belgium, 2019.

2. Lavell, A.; Oppenheimer, M.; Diop, C.; Hess, J.; Lempert, R.; Li, J.; Muir-Wood, R.; Myeong, S.; Moser, S.; Takeuchi, K.; et al. Climate Change: New Dimensions in Disaster Risk, Exposure, Vulnerability, and Resilience; Cambridge University Press: Cambridge, UK, 2012; Volume 9781107025.

3. Jongman, B.; Winsemius, H.C.; Aerts, J.C.J.H.; Coughlan de Perez, E.; van Aalst, M.K.; Kron, W.; Ward, P.J. Declining vulnerability to river floods and the global benefits of adaptation. Proc. Natl. Acad. Sci. USA 2015, 112, E2271-E2280. [CrossRef]

4. Brandimarte, L.; Brath, A.; Castellarin, A.; Baldassarre, G. Di Isla Hispaniola: A trans-boundary flood risk mitigation plan. Phys. Chem. Earth 2009, 34, 209-218. [CrossRef]

5. Dawson, R.J.; Ball, T.; Werritty, J.; Werritty, A.; Hall, J.W.; Roche, N. Assessing the effectiveness of non-structural flood management measures in the Thames Estuary under conditions of socio-economic and environmental change. Glob. Environ. Chang. 2011, 21, 628-646. [CrossRef] 
6. Vis, M.; Klijn, F.; Bruijn, K.M.D.; Buuren, M. Van Resilience strategies for flood risk management in the netherlands. Int. J. River Basin Manag. 2003, 1, 33-40. [CrossRef]

7. Kreibich, H.; Di Baldassarre, G.; Vorogushyn, S.; Aerts, J.C.J.H.; Apel, H.; Aronica, G.T.; Arnbjerg-Nielsen, K.; Bouwer, L.M.; Bubeck, P.; Caloiero, T.; et al. Adaptation to flood risk: Results of international paired flood event studies. Earth's Future 2017, 5, 953-965. [CrossRef]

8. Buchecker, M.; Salvini, G.; Di Baldassarre, G.; Semenzin, E.; Maidl, E.; Marcomini, A. The role of risk perception in making flood risk management more effective. Nat. Hazards Earth Syst. Sci. 2013, 13, 3013-3030. [CrossRef]

9. Wachinger, G.; Renn, O.; Begg, C.; Kuhlicke, C. The risk perception paradox-implications for governance and communication of natural hazards. Risk Anal. 2013, 33, 1049-1065. [CrossRef] [PubMed]

10. Botzen, W.J.W.; Aerts, J.C.J.H.; Van Den Bergh, J.C.J.M. Dependence of flood risk perceptions on socioeconomic and objective risk factors. Water Resour. Res. 2009, 45, 1-15. [CrossRef]

11. Fielding, J.L. Inequalities in exposure and awareness of flood risk in England and Wales. Disasters 2012, 36, 477-494. [CrossRef] [PubMed]

12. Grothmann, T.; Patt, A. Adaptive capacity and human cognition: The process of individual adaptation to climate change. Glob. Environ. Chang. 2005, 15, 199-213. [CrossRef]

13. Miceli, R.; Sotgiu, I.; Settanni, M. Disaster preparedness and perception of flood risk: A study in an alpine valley in Italy. J. Environ. Psychol. 2008, 28, 164-173. [CrossRef]

14. Mileti, D.S.; O’Brien, P. Public response to aftershock warnings. In US Geological Survey Professional Paper; United States Government Publishing Office: Washington, DC, USA, 1993.

15. Whitmarsh, L. Are flood victims more concerned about climate change than other people? The role of direct experience in risk perception and behavioural response. J. Risk Res. 2008, 11, 351-374. [CrossRef]

16. Comănescu, L.; Nedelea, A. Floods and Public Perception on their Effect. Case Study: Tecuci Plain (Romania), Year 2013. Procedia Environ. Sci. 2016, 32, 190-199. [CrossRef]

17. Bradford, R.A.; O’Sullivan, J.J.; Van Der Craats, I.M.; Krywkow, J.; Rotko, P.; Aaltonen, J.; Bonaiuto, M.; De Dominicis, S.; Waylen, K.; Schelfaut, K. Risk perception-Issues for flood management in Europe. Nat. Hazards Earth Syst. Sci. 2012, 12, 2299-2309. [CrossRef]

18. Green, C.H.; Tunstall, S.M.; Fordham, M.H. The risks from flooding: Which risks and whose perception? Disasters 1991, 15, 227-236. [CrossRef] [PubMed]

19. Lawrence, J.; Quade, D.; Becker, J. Integrating the effects of flood experience on risk perception with responses to changing climate risk. Nat. Hazards 2014, 74, 1773-1794. [CrossRef]

20. Qasim, S.; Nawaz Khan, A.; Prasad Shrestha, R.; Qasim, M. Risk perception of the people in the flood prone Khyber Pukhthunkhwa province of Pakistan. Int. J. Disaster Risk Reduct. 2015, 14, 373-378. [CrossRef]

21. Wachinger, G.; Renn, O. Risk Perception and Natural Hazards; CapHaz-Net WP3 Report; DIALOGIK Non-Profit Institute for Communication and Cooperative Research: Stuttgart, Germany, 2010.

22. Bustillos Ardaya, A.; Evers, M.; Ribbe, L. What influences disaster risk perception? Intervention measures, flood and landslide risk perception of the population living in flood risk areas in Rio de Janeiro state, Brazil. Int. J. Disaster Risk Reduct. 2017, 25, 227-237. [CrossRef]

23. Ho, M.-C.; Shaw, D.; Lin, S.; Chiu, Y.-C. How Do Disaster Characteristics Influence Risk Perception? Risk Anal. 2008, 28, 635-643. [CrossRef]

24. Halpern-Felsher, B.L.; Millstein, S.G.; Ellen, J.M.; Adler, N.E.; Tschann, J.M.; Biehl, M. The role of behavioral experience in judging risks. Health Psychol. 2001, 20, 120-126. [CrossRef]

25. Burningham, K.; Fielding, J.; Thrush, D. "It'll never happen to me": Understanding public awareness of local flood risk. Disasters 2008, 32, 216-238. [CrossRef] [PubMed]

26. Knuth, D.; Kehl, D.; Hulse, L.; Schmidt, S. Risk Perception, Experience, and Objective Risk: A Cross-National Study with European Emergency Survivors. Risk Anal. 2014, 34, 1286-1298. [CrossRef]

27. Scolobig, A.; De Marchi, B.; Borga, M. The missing link between flood risk awareness and preparedness: Findings from case studies in an Alpine Region. Nat. Hazards 2012, 63, 499-520. [CrossRef]

28. Siegrist, M.; Gutscher, H.; Earle, T.C. Perception of risk: The influence of general trust, and general confidence. J. Risk Res. 2005, 8, 145-156. [CrossRef]

29. Santoro, S.; Pluchinotta, I.; Pagano, A.; Pengal, P.; Cokan, B.; Giordano, R. Assessing stakeholders' risk perception to promote Nature Based Solutions as flood protection strategies: The case of the Glinščica river (Slovenia). Sci. Total Environ. 2019, 655, 188-201. [CrossRef] [PubMed] 
30. Bera, M.K.; Daněk, P. The perception of risk in the flood-prone area: A case study from the Czech municipality. Disaster Prev. Manag. Int. J. 2018, 27, 2-14. [CrossRef]

31. Thistlethwaite, J.; Henstra, D.; Brown, C.; Scott, D. How Flood Experience and Risk Perception Influences Protective Actions and Behaviours among Canadian Homeowners. Environ. Manag. 2018, 61, 197-208. [CrossRef]

32. Becker, G.; Aerts, J.C.J.H.; Huitema, D. Influence of flood risk perception and other factors on risk-reducing behaviour: A survey of municipalities along the Rhine. J. Flood Risk Manag. 2014, 7, 16-30. [CrossRef]

33. Steinführer, A.; Kuhlicke, C. Social Vulnerability and the 2002 Flood. County Report Germany (Mulde River); Helmholz Unweltforschungszentrum (UFZ): Leipzig, Germany, 2007.

34. De Marchi, B.; Scolobig, A.; Delli Zotti, G.; Del Zotto, M. Risk Construction and Social Vulnerability in an Italian Alpine Region; Report T11-07-12 of FLOODsite Integrated Project; European Commission: Brussels, Belgium, 2007.

35. Grothmann, T.; Reusswig, F. People at risk of flooding: Why some residents take precautionary action while others do not. Nat. Hazards 2006, 38, 101-120. [CrossRef]

36. Slovic, P. Perception of Risk. Adv. Sci. 1987, 236, 280-285. [CrossRef]

37. Sibthorpe, B. The Social Construction of Sexual Relationships as a Determinant of HIV Risk Perception and Condom Use among Injection Drug Users. Med. Anthropol. Q. 1992, 6, 255-270. [CrossRef]

38. Rothman, S.; Lichter, R. Elite Ideology and Risk Perception in Nuclear Energy Policy. Am. Polit. Sci. Rev. 1987, 81, 383-404. [CrossRef]

39. Dretske, F. Conscious Experience. Mind Assoc. 1993, 102, 263-283. [CrossRef]

40. Cattaneo, Z.; Silvanto, J. Mental Imagery: Visual Cognition. In International Encyclopedia of the Social $\mathcal{E}$ Behavioral Sciences, 2nd ed.; Wrigth, J.D., Ed.; Elsevier: Amsterdam, The Netherlands, 2015; Volume 15, pp. 220-227. ISBN 9780080970875.

41. Gallese, V. The manifold nature of interpersonal relations: The quest for a common mechanism. Philos. Trans. R. Soc. B Biol. Sci. 2003, 358, 517-528. [CrossRef] [PubMed]

42. Park, C.W.; Gardner, M.P.; Thukral, V.K. Self-Perceived Knowledge: Some Effects on Information Processing for a Choice Task. Am. J. Psychol. 1988, 101, 401. [CrossRef]

43. Stoutenborough, J.W.; Vedlitz, A. The effect of perceived and assessed knowledge of climate change on public policy concerns: An empirical comparison. Environ. Sci. Policy 2014, 37, 23-33. [CrossRef]

44. Meeds, R. Cognitive and attitudinal effects of technical advertising copy: The roles of gender, self-assessed and objective consumer knowledge. Int. J. Advert. 2004, 23, 309-335. [CrossRef]

45. Fischhoff, B.; Slovic, P.; Lichtenstein, S.; Read, S.; Combs, B. How safe is safe enough? A psychometric study of attitudes towards technological risks and benefits. Policy Sci. 1978, 9, 127-152. [CrossRef]

46. Slovic, P. Trust, emotion, sex, politics and science: Surveying the risk-assessment battlefield. Percept. Risk 1999, 19, 390-412. [CrossRef]

47. Kellens, W.; Terpstra, T.; De Maeyer, P. Perception and Communication of Flood Risks: A Systematic Review of Empirical Research. Risk Anal. 2013, 33, 24-49. [CrossRef]

48. Weichselgartner, J.; Pigeon, P. The Role of Knowledge in Disaster Risk Reduction. Int. J. Disaster Risk Sci. 2015, 6, 107-116. [CrossRef]

49. Centro Funzionale Decentrato. Bollettino di Nowcasting; Verona. Regione del Veneto: Venice, Italy, 2018. Available online: https:/www.regione.veneto.it/c/document_library/get_file?uuid=5f95c794-6a46-4893-93410b74db6edc83\&groupId=90748 (accessed on 7 July 2020).

50. Borga, M. Piena improvvisa del 1 settembre 2018 sul Progno di Novare-Valutazione del carattere di eccezionalità della precipitazione innescante; University of Padua: Padua, Italy, 2018.

51. Roder, G.; Hudson, P.; Tarolli, P. Flood risk perceptions and the willingness to pay for flood insurance in the Veneto region of Italy. Int. J. Disaster Risk Reduct. 2019, 37, 1-10. [CrossRef]

52. Sofia, G.; Roder, G.; Dalla Fontana, G.; Tarolli, P. Flood dynamics in urbanised landscapes: 100 years of climate and humans' interaction. Sci. Rep. 2017, 7, 1-12.

53. Amponsah, W.; Ayral, P.A.; Boudevillain, B.; Bouvier, C.; Braud, I.; Brunet, P.; Delrieu, G.; DIdon-Lescot, J.F.; Gaume, E.; Lebouc, L.; et al. Integrated high-resolution dataset of high-intensity European and Mediterranean flash floods. Earth Syst. Sci. Data 2018, 10, 1783-1794. [CrossRef]

54. Borga, M.; Comiti, F.; Ruin, I.; Marra, F. Forensic analysis of flash flood response. Wiley Interdiscip. Rev. Water 2019, 6, 1-9. [CrossRef] 
55. Stockemer, D. Quantitative Methods for the Social Sciences-A Practical Introduction with Examples in SPSS and Stata, I ed.; Springer International Publishing: Cham, Switzerland, 2019.

56. Weyrich, P.; Mondino, E.; Borga, M.; Di Baldassarre, G.; Patt, A.; Scolobig, A. A flood-risk-oriented, dynamic protection motivation framework to explain risk reduction behaviours. Nat. Hazards Earth Syst. Sci. 2020, 20, 287-298. [CrossRef]

57. Christensen, R.H.B.C. Ordinal: Regression Models for Ordinal Data. R package version 2019.12-10. 2019.

58. Liu, D.; Li, Y.; Shen, X.; Xie, Y.; Zhang, Y. Flood risk perception of rural households in western mountainous regions of Henan Province, China. Int. J. Disaster Risk Reduct. 2018, 27, 155-160. [CrossRef]

59. De Vries, D.H. Temporal Vulnerability and the Post-Disaster 'Window of Opportunity to Woo': A Case Study of an African-American Floodplain Neighborhood after Hurricane Floyd in North Carolina. Hum. Ecol. 2017, 45, 437-448. [CrossRef]

60. Aristotle Book VI. In Nichomachaean Ethics; Cambridge University Press: Cambridge, UK, 2020.

61. Polanyi, M. The Tacit Dimension; Doubleday: Chicago, IL, USA, 1966.

(C) 2020 by the authors. Licensee MDPI, Basel, Switzerland. This article is an open access article distributed under the terms and conditions of the Creative Commons Attribution (CC BY) license (http://creativecommons.org/licenses/by/4.0/). 